\title{
Prospective, Randomized, comparative study between aprotinin and tranexamic acid in cardiac surgery
}

\author{
Rabie Soliman ${ }^{3 *}$, Hassan Yousef ${ }^{4}$, Faisal Alghadam¹, Adel Ragheb', Mohamed Hussein ${ }^{5}$, Howaida Al Qethamy ${ }^{1}$, Makhlouf Belghith ${ }^{1}$ \\ and Tarek Abdel Mageed ${ }^{2,3}$ \\ *Correspondence: rabiesoliman@hotmail.com \\ 'Prince Sultan cardiac center, Riyadh, Saudi Arabia. \\ ${ }^{2}$ Madinah cardiac center, Madinah, Saudi Arabia. \\ ${ }^{3}$ Cairo University, Egypt. \\ ${ }^{4}$ Ein Shams University, Egypt. \\ ${ }^{5}$ Alazhar Unversity, Egypt.
}

\begin{abstract}
Background: Cardiac surgery is associated with perioperative bleeding and a significant consumption of allogenic blood products. Minimizing blood loss and transfusion requirements is of vital importance to avoid complication related to blood products transfusion. This study was done to compare the hemostatic effects of aprotinin and tranexamic acid (TA) on reducing bleeding and blood products transfusion in adult cardiac surgery.

Methods: A prospective study involved 100 patients, classified randomly into two groups ( $\mathrm{N}=50$ each). Group A patients received intravenous infusion of 2000000 kallikrein inhibitory units (KIU) of aprotinin over 30 minutes, then infusion of $500000 \mathrm{KIU} / \mathrm{hr}$ throughout the operation and 2000000 aprotinin KIU) were added to the CPB circuit. Group B patients received TA as $20 \mathrm{mg} / \mathrm{kg}$ over 10 minutes, then infusion $5 \mathrm{mg} / \mathrm{kg} / \mathrm{hr}$ throughout the operation. The effects of aprotinin and TA were monitored by ACT, PT, INR, aPTT, platelets, fibrinogen, D-dimer, troponin I, blood losses, blood products transfusion, duration of thorax closure and serum creatinine level.

Results: Both groups were comparable in their baseline demographic and surgical characteristics. The differences of ACT, PT, INR, aPTT, platelets, heparin dose, serum creatinine level, troponin I, and mortality between the two groups were insignificant $(\mathrm{P}>0.05)$. The blood losses, blood products transfusion, fibrinogen, $\mathrm{D}$-dimer and thorax closure time were all significantly higher in group $\mathrm{B}(\mathrm{P}<0.05)$. There was a statistically insignificant higher incidence of acute renal failure in group A.

Conclusion: Aprotinin decreases fibrinolysis, blood losses, and need for blood products transfusion in comparison to TA during adult cardiac surgery. It is however associated with a trend for an increased incidence of acute renal failure. Use of aprotinin should be useful for cases at high risk for bleeding such as redo surgery. It should be used cautiously in patients with preoperative renal impairment.
\end{abstract}

Keywords: Adult cardiac surgery, aprotinin, tranexamic acid, cardiopulmonary bypass, blood loss, blood products transfusion

\section{Introduction}

Cardiopulmonary bypass (CPB) alters the hemostatic balance and predisposes cardiac surgery patients to an increased risk of coagulopathy and excessive perioperative bleeding [1]. This is one of the main causes of postoperative morbidity in cardiac surgical patients who require transfusion of blood components after cardiopulmonary CPB [2]. The pathophysiology of bleeding after CPB is multifactorial and complex, involving hypothermia, hemodilution, activation of coagulation, endothelial cell and tissue injury, foreign-surface contact, consumption of clotting factors, platelets activation, platelets dysfunction and hyperfibrinolysis $[3,4,5]$. Thrombin level increases during CPB despite systemic heparinization. This leads to generalized fibrinolysis during and immediately after CPB, with deleterious effects on platelets function. Increased fibrinolytic activity and platelets dysfunction are important causes of postoperative bleeding [4].
Procedures such as autologous blood predonation, isovolumic hemodilution, and equipment for blood cell saving [6], in addition to antifibrinolytic drugs such as aprotinin, tranexamic acid and $\varepsilon$-aminocaproic acid, were introduced in cardiac surgery to reduce the need for allogenic blood transfusions. Anti-fibrinolytic drugs are used to prevent platelets dysfunction and decrease perioperative bleeding. Varying results in terms of perioperative blood loss and blood transfusion requirements in different clinical settings have been described with the use of tranexamic acid and aprotinin [7].

The mechanism of action of aprotinin is complex. This agent has anti-inflammatory and anticoagulant properties that preserve hemostasis by inhibiting the contact pathway and possibly the tissue-factor pathway [8]. Aprotinin reversibly complexes with the active serine site in various proteases, including trypsin, plasmin, and kallikrein. It inhibits factor XIla, 
activation of complement, and kallikrein- mediated conversion of plasminogen to plasmin, thereby diminishing fibrinolysis, the increase in D-dimer levels and decreases thrombin generation during CPB $[\mathbf{9}, \mathbf{1 0}, \mathbf{1 1}]$.

Tranexamic acid is a synthetic lysine analogue antifibrinolytic drug. It acts by forming a reversible complex with plasminogen and plasmin through the lysine-binding sites, thereby blocking interaction with the specific lysine residues of fibrin. Although plasmin is still formed, it is unable to bind to fibrinogen. This minimizes the increase in primary fibrinolysis that occurs during CPB. Tranexamic acid preserves platelets function by reducing the effect of plasmin on platelets glycoprotein $1 \mathrm{~b}$ receptors $[12,13]$.

Our study was performed to compare the hemostatic effects of aprotinin and tranexamic acid on reducing bleeding and blood products transfusion in adult cardiac surgery patients.

\section{Methods}

The study was carried out as a prospective randomized investigation. After local ethics committee approval, all patients scheduled for coronary artery bypass graft (CABG) or valve surgery at Prince Sultan Cardiac Center, Riyadh, Saudi Arabia, during the period from December 2007 to November 2010, were screened for eligibility enrolment. The exclusion criteria included patients who had preoperative coagulopathy, recent administration of antiplatelets or anticoagulants (aspirin $<5$ days, heparin $<4$ hours, low molecular weight heparin $<12$ hours, clopidogrel $<7$ days, warfarin $<3$ days, or thrombolytic therapy $<24$ hours preoperatively), preexisting renal dysfunction (serum creatinine $>115 \mathrm{mmol} / \mathrm{l}$ ), elevated liver enzymes more than 2 folds (aspartate transaminase, alanine transaminase and alkaline phosphatase), or aortic aneurysm surgery.

One hundred patients met the requirements for inclusion, and informed consent was obtained from all of them. The patients were randomly allocated into one of the two groups (50 patients in each group). Group A (aprotinin, Trasylol, Bayer AG Germany): The patients received intravenous infusion of 2 000000 kallikrein inhibitory units (KIU) of aprotinin over 30 minutes, then $5000 \mathrm{KIU} / \mathrm{hr}$ of aprotinin were administered continuously throughout the operation, until skin closure. In addition, $2000000 \mathrm{KIU}$ were added to the priming solution of the CPB circuit.

Group B (Tranexamic acid, Cyklokapron, Pfizer, Belgium): The patients received tranexamic acid as $20 \mathrm{mg} / \mathrm{kg}$ as a bolus dose over 10 minutes, then infusion $5 \mathrm{mg} / \mathrm{kg} / \mathrm{hr}$ after induction and continuously throughout the operation until skin closure.

Anaesthetic techniques included a variety of drugs, including etomidate, rocuronium, fentanyl, propofol, and sevoflurane, often in combination. All patients received 4mg/ $\mathrm{kg}$ of heparin before bypass, aiming to provide an activated clotting time (ACT) $>480$ seconds. After bypass, heparin was reversed with protamine which was titrated to achieve an ACT $<140$ seconds. CPB used centrifugal pumps with 1 to $1.5 \mathrm{~L}$ prime of ringer lactate, in addition to antibiotics, solu- medrol and mannitol. Both antegrade and retrograde blood cardioplegia were used. Cooling was passive to around $34^{\circ} \mathrm{C}$ or active to $22^{\circ} \mathrm{C}$. Packed red cells were administered to keep hemoglobin above $9 \mathrm{~g} / \mathrm{dl}$. Platelets, fresh frozen plasma, and cryoprecipitate were administered either intraoperatively if there was excessive generalized oozing with inability to close the chest, or postoperatively, if the chest drains loss was more than $3 \mathrm{ml} / \mathrm{kg} / \mathrm{hr}$. Acute renal failure was diagnosed according to RIFLE criteria [14].

\section{Patients monitoring}

For all patients, the following variables were closely monitored; the mean arterial pressure (MAP), heart rate, central venous pressure (CVP), laboratory investigations including hemoglobin, activated clotting time(ACT), prothrombin time(PT), international normalized ratio(INR), activated partial thromboplastin time (aPTT), platelets, fibrinogen, Ddimer, troponin I, and creatinine. Also the thorax closure time, amount of blood losses, blood products transfusion through the postoperative 24 hours were monitored. Chest X-ray (CXR) was done preoperatively and on admission to CSICU, and as indicated to rule out widened mediastinum.

\section{Statistical methods}

Data were statistically described in terms of mean \pm standard deviation $( \pm S D)$, or frequencies (number of cases) and percentages when appropriate. Comparison of numerical variables between the study groups was done using Student $t$ test for independent samples. For comparing categorical data, Chi square $\left(\mathrm{X}^{2}\right)$ test was performed. Exact test was used instead when the expected frequency is less than 5 . P-values less than 0.05 was considered statistically significant. All statistical calculations were done using computer programs SPSS (Statistical Package for the Social Science; SPSS Inc., Chicago, IL, USA) version 15 for Microsoft Windows.

\section{Results \\ Preoperative clinical data of Patients}

Group A included 23 male and 27 female patient and group $B$ included 26 male patient and 24 female patient. The mean age of group A patients was $49.10 \pm 16.65$ year and group $B$ was $48.12 \pm 16.09$ year $(P=0.786)$. The mean weight of group A patients was $81.57 \pm 19.74 \mathrm{~kg}$ and group $B$ was $83.30 \pm 19.05$ $\mathrm{kg}(P=0.692)$. Regarding the preoperative medical diseases and anticoagulants, there was no significant difference ( $P>0.05$ ) (Table 1).

\section{Surgical Data of patients}

The elective cases included 40 patients in group $A$ and 44 patients in group $B(P=0.556)$, and the emergency cases were 10 patients in group $A$ and 6 patients in group $B(P=0.709)$. There were 15 CABG patients in group $A$ and 19 CABG patient in group $B(P=0.464), 23$ patient had $C A B G$ with valvular surgery and 26 patients in group $B(P=0.502)$, and 12 patients had 
Soliman et al. Journal of Anesthesiology and Clinical Science 2013, http://www.hoajonline.com/journals/pdf/2049-9752-2-13.pdf

doi: $10.7243 / 2049-9752-2-13$

Table 1. Preoperative data of patients.

\begin{tabular}{|c|c|c|c|c|}
\hline \multicolumn{2}{|c|}{ Item } & \multirow{2}{*}{$\begin{array}{c}\begin{array}{c}\text { Group A } \\
(\mathbf{n}=\mathbf{5 0})\end{array} \\
23(46 \%) \\
27(54 \%)\end{array}$} & \multirow{2}{*}{$\begin{array}{c}\begin{array}{c}\text { Group B } \\
(\mathbf{n}=\mathbf{5 0 )}\end{array} \\
26(52 \%) \\
24(48 \%)\end{array}$} & \multirow{2}{*}{$\begin{array}{c}\text { P-value } \\
0.499 \\
0.735\end{array}$} \\
\hline Sex & $\begin{array}{l}\text { male } \\
\text { female }\end{array}$ & & & \\
\hline \multicolumn{2}{|c|}{ Age (year) } & $49.10 \pm 16.65$ & $48.12 \pm 16.09$ & 0.786 \\
\hline \multicolumn{2}{|c|}{ Weight(Kg) } & $81.57 \pm 19.74$ & $83.30 \pm 19.05$ & 0.692 \\
\hline \multicolumn{2}{|c|}{ Hypertension } & $11(22 \%)$ & $10(20 \%)$ & 0.691 \\
\hline \multicolumn{2}{|l|}{ DM } & $12(24 \%)$ & $9(18 \%)$ & 0.446 \\
\hline \multicolumn{2}{|c|}{ Serum creatinine $(\mathrm{mmol} / \mathrm{l})$} & $74 \pm 22$ & $79 \pm 25$ & 0.633 \\
\hline \multicolumn{2}{|c|}{ Elevated liver enzymes $<2$ folds } & $6(12 \%)$ & $4(8 \%)$ & 0.105 \\
\hline \multicolumn{2}{|c|}{ Carotid stenosis $<50 \%$} & $2(4 \%)$ & $4(8 \%)$ & 0.217 \\
\hline \multicolumn{2}{|l|}{ MI } & $3(6 \%)$ & $4(8 \%)$ & 0.385 \\
\hline \multicolumn{2}{|c|}{ Tropinin I(ng/ml) } & $0.046 \pm 0.128$ & $0.041 \pm 0.149$ & 0.736 \\
\hline \multicolumn{2}{|c|}{ Aspirin } & $17(34 \%)$ & $13(26 \%)$ & 0.648 \\
\hline \multicolumn{2}{|c|}{ Clopidogrel } & $12(24 \%)$ & $15(30 \%)$ & 0.457 \\
\hline \multicolumn{2}{|c|}{ Warfarin } & $14(28 \%)$ & $10(20 \%)$ & 0.251 \\
\hline \multicolumn{2}{|c|}{ Heparin } & $8(16 \%)$ & $5(10 \%)$ & 0.827 \\
\hline \multicolumn{2}{|c|}{ LMWH } & $3(6 \%)$ & $2(4 \%)$ & 0.208 \\
\hline \multicolumn{2}{|c|}{$\mathrm{EF} \%$} & $43.12 \pm 11.24$ & $39.25 \pm 10.89$ & 0.122 \\
\hline \multicolumn{2}{|c|}{ Euro score } & $6.19 \pm 2.87$ & $6.58 \pm 3.01$ & 0.557 \\
\hline \multicolumn{2}{|c|}{$\mathrm{HB}(\mathrm{g} / \mathrm{dl})$} & $12.69 \pm 2.55$ & $12.61 \pm 2.68$ & 0.898 \\
\hline
\end{tabular}

DM: diabetes mellitus, LMWH: low molecular weight heparin, HB: hemoglobin, EF: ejection fraction, MI: Acute myocardial infarction, Values are expressed as mean (SD), numbers (\%).

Table 2. Surgical data of patients.

\begin{tabular}{|c|c|c|c|c|}
\hline \multicolumn{2}{|l|}{ Item } & $\begin{array}{c}\text { Group } \\
\mathbf{A}(\mathbf{n}=50)\end{array}$ & $\begin{array}{c}\text { Group } \\
\mathrm{B}(\mathrm{n}=\mathbf{5 0})\end{array}$ & P-value \\
\hline \multicolumn{2}{|c|}{ Elective surgery } & $40(80 \%)$ & $44(88 \%)$ & 0.556 \\
\hline \multicolumn{2}{|c|}{ Emergency surgery } & $10(20 \%)$ & $6(12 \%)$ & 0.709 \\
\hline \multicolumn{2}{|l|}{ CABG } & $15(30 \%)$ & $19(38 \%)$ & 0.464 \\
\hline \multicolumn{2}{|c|}{ CABG+ Valvular Surgery } & $23(46 \%)$ & $26(52 \%)$ & 0.502 \\
\hline \multicolumn{2}{|c|}{ Valvular Surgery } & $12(24 \%)$ & $5(10 \%)$ & 0.056 \\
\hline \multirow{3}{*}{ REDO } & CABG & $2(4 \%)$ & $5(10 \%)$ & 0.463 \\
\hline & $\begin{array}{l}\text { CABG+Valvular } \\
\text { Surgery }\end{array}$ & $2(4 \%)$ & $3(6 \%)$ & 0.637 \\
\hline & Valvular Surgery & $4(8 \%)$ & $2(4 \%)$ & 0.325 \\
\hline \multicolumn{2}{|c|}{ СРB time(minute) } & $123.652 \pm 3.84$ & $119.90 \pm 23.01$ & 0.467 \\
\hline \multicolumn{2}{|c|}{ Cross-clamping time(minute) } & $95.30 \pm 22.55$ & $98.60 \pm 20.96$ & 0.316 \\
\hline \multicolumn{2}{|c|}{ Temperature $\left({ }^{\circ} \mathrm{C}\right)$} & $29.45 \pm 2.93$ & $28.33 \pm 3.39$ & 0.117 \\
\hline \multicolumn{2}{|c|}{ Total heparin dose(mg) } & $314.13 \pm 62.34$ & $304.00 \pm 74.85$ & 0.511 \\
\hline \multicolumn{2}{|c|}{ Post heparin ACT( second) } & $572.43 \pm 110.20$ & $618.73 \pm 131.91$ & 0.092 \\
\hline \multicolumn{2}{|c|}{ Total protamine dose(mg) } & $326.25 \pm 60.10$ & $310.75 \pm 74.25$ & 0.355 \\
\hline \multicolumn{2}{|c|}{ Post- protamine $\mathrm{ACT}$ (second) } & $133.30 \pm 13.88$ & $136.38 \pm 15.61$ & 0.308 \\
\hline \multicolumn{2}{|c|}{ Thorax closure time (minute) } & $77.87 \pm 13.90$ & $86.63 \pm 14.81$ & 0.007 \\
\hline \multicolumn{2}{|c|}{ Re-exploration } & $1(2 \%)$ & $2(4 \%)$ & 1.000 \\
\hline
\end{tabular}

CABG: coronary artery bypass grafting, CPB: Cardiopulmonary bypass, ACT: Activated clotting time .Values are expressed mean(SD), numbers (\%).

only valvular surgery in group $A$ in comparison to 5 patients in group $B(P=0.056)$. The redo cases were $2 \mathrm{CABG}$ cases in group $A$ and 5 cases in group $B(P=0.463), 2 C A B G$ and valvular surgery cases in group $A$ and 3 cases in group $B(P=0.637)$, 4 valvular surgery cases in group $A$ and 2 cases in group $B(P=0.325)$. Re-exploration was needed in one patient in group $A$ and 2 patients in group $B(P=1.000)$, and in all cases the bleeding was due to generalized oozing. The mean thorax closure time was $77.87 \pm 13.90$ minutes in group $A$ and $86.63 \pm 14.81$ minutes in group $B(P=0.007)$ (Table 2$)$.

\section{Cardiopulmonary bypass data of patients}

The mean heparin dose was $314.13 \pm 62.34 \mathrm{mg}$ in group $A$ and $304.00 \pm 74.85 \mathrm{mg}$ in group $B(P=0.511)$ and the mean $A C T$ was $572.43 \pm 110.20$ seconds in group $A$ and $618.73 \pm 131.91$ seconds in group $B(P=0.092)$. After weaning from $C P B$, and stabilization of the patients, protamine was given. The mean dose of protamine was $326.25 \pm 60.10 \mathrm{mg}$ in group $A$ and $310.75 \pm 74.25$ $\mathrm{mg}$ in group $B(P=0.355)$. The mean $A C T$ after protamine was $133.30 \pm 13.88$ seconds in group $A$ and $136.38 \pm 5.61$ seconds in group $B(P=0.308)$. The mean duration of $C P B$ time was $123.65 \pm 23.84$ minute in group $A$ and $119.90 \pm 23.01$ minute in group $B(P=0.467)$. The aortic cross clamping time was $95.30 \pm 22.55$ minute in group $A$ and $98.60 \pm 20.96$ minute in group $B(P=0.316)$ and the mean temperature during $C P B$ was $29.83 \pm 2.91^{\circ} \mathrm{C}$ in group $\mathrm{A}$ and $28.33 \pm 3.39^{\circ} \mathrm{C}$ in group $\mathrm{B}(\mathrm{P}=0.117)$ (Table 2).

\section{Coagulation profiles}

The mean preoperative PT in group A was $10.61 \pm 0.92$ seconds and $11.12 \pm 1.28$ seconds in group $B(P=0.051)$. The mean INR was $1.02 \pm 0.12$ in group $A$ and $1.05 \pm 0.10$ in group $B(P=0.140)$. The mean aPTT was $40.02 \pm 7.92$ seconds in group $A$ and $41.60 \pm 9.02$ seconds in group $B(P=0.431)$. The mean $A C T$ was $135.70 \pm 12.28$ seconds in group $A$ and $138.67 \pm 16.21$ seconds in group $B(P=0.358)$. The mean preoperative platelets number was $288.35 \pm 76.21\left(\times 10^{3} / \mu l\right)$ in group $A$ and $303.35 \pm 101.96\left(\times 10^{3} /\right.$ $\mu \mathrm{ll}$ ) in group $\mathrm{B}(\mathrm{P}=0.458)$ (Tables 3,4$)$. The mean postoperative $\mathrm{PT}$ was $10.05 \pm 1.04$ seconds in group $A$ and $10.13 \pm 1.13$ seconds in group $B(P=0.744)$. The mean INR was $1.20 \pm 0.22$ in group $A$ and $1.18 \pm 0.20$ in group $B(P=0.942)$. The mean aPTT was $41.60 \pm 7.56$ seconds in group $A$ and $41.38 \pm 7.71$ seconds in group $B(P=0.896)$. The mean $A C T$ was $130.2 \pm 11.7$ seconds in group $A$ and $127.2 \pm 15.4$ seconds in group $B(P=0.245)$. The mean postoperative platelets number was $254.63 \pm 61.40\left(\times 10^{3} /\right.$ $\mu l)$ in group $A$ and $255.90 \pm 59.10\left(\times 10^{3} / \mu l\right)$ in group $B(P=0.060)$ (Tables 3,4).

\section{Fibrinogen and D-dimer}

The mean preoperative level of fibrinogen was $3.57 \pm 0.51$ $\mathrm{g} / \mathrm{l}$ in group $A$ and $3.51 \pm 0.55 \mathrm{~g} / \mathrm{l}$ in group $B(P=0.625)$. The postoperative level mildly decreased in group $A$ patients $(3.25 \pm 0.51 \mathrm{~g} / \mathrm{l})$ and decreased greatly in patients of group $B(2.56 \pm 0.48 \mathrm{~g} / \mathrm{l})(\mathrm{P}=0.001)$ (Tables 3,4$)$. The preoperative $D$-dimer level was within normal range in patients of both groups. The mean level was $0.27 \pm 0.116 \mu \mathrm{g} / \mathrm{ml}$ in group $A$ and $0.27 \pm 0.117 \mu \mathrm{g} / \mathrm{ml}$ in group $B(P=0.848)$. Postoperatively, the $D$-dimer mildly increased in group A patients $(1.12 \pm 0.429$ $\mu \mathrm{g} / \mathrm{ml})$ and greatly increased in group B patients $(2.33 \pm 0.709$ $\mu \mathrm{g} / \mathrm{ml})(P=0.001)($ Tables 3,4). 
Soliman et al. Journal of Anesthesiology and Clinical Science 2013,

http://www.hoajonline.com/journals/pdf/2049-9752-2-13.pdf

doi: 10.7243/2049-9752-2-13

Table 3. Preoperative coagulation profiles of patients.

\begin{tabular}{lccc}
\hline Item & Group A(n=50) & Group B(n=50) & P-value \\
\hline PT(second) & $10.61 \pm 0.92$ & $11.12 \pm 1.28$ & 0.051 \\
INR & $1.02 \pm 0.12$ & $1.03 \pm 0.10$ & 0.140 \\
aPTT(second) & $40.02 \pm 7.92$ & $41.60 \pm 9.02$ & 0.431 \\
ACT(second) & $135.70 \pm 12.28$ & $138.67 \pm 16.21$ & 0.358 \\
Platelets $\left(x 10^{3} / \mu \mathrm{l}\right)$ & $288.35 \pm 76.21$ & $303.35 \pm 101.96$ & 0.458 \\
Fibrinogen $(\mathrm{g} / \mathrm{l})$ & $3.57 \pm 0.51$ & $3.51 \pm 0.55$ & 0.625 \\
D-dimer $(\mu \mathrm{g} / \mathrm{ml})$ & $0.27 \pm 0.116$ & $0.27 \pm 0.117$ & 0.848 \\
\hline
\end{tabular}

PT: prothrombin time, INR:international normalized ratio, aPTT : activated thromboplastin time, ACT: activated clotting time. Values are expressed as mean(SD).

Table 4. Postoperative coagulation profiles of patients.

\begin{tabular}{lccc}
\hline Item & Group A(n=50) & Group B(n=50) & P-value \\
\hline PT(second) & $10.05 \pm 1.04$ & $10.13 \pm 1.13$ & 0.744 \\
INR & $1.20 \pm 0.22$ & $1.18 \pm 0.20$ & 0.942 \\
aPTT(second) & $41.60 \pm 7.56$ & $41.38 \pm 7.71$ & 0.896 \\
ACT(second) & $130.2 \pm 11.7$ & $127.2 \pm 15.4$ & 0.245 \\
Platelets $\left(\mathrm{x} 10^{3} / \mu \mathrm{l}\right)$ & $254.63 \pm 61.40$ & $255.90 \pm 59.10$ & 0.060 \\
Fibrinogen $(\mathrm{g} / \mathrm{l})$ & $3.25 \pm 0.51$ & $2.56 \pm 0.48$ & 0.001 \\
D-dimer $(\mu \mathrm{g} / \mathrm{ml})$ & $1.12 \pm 0.42^{*}$ & $2.33 \pm 0.70^{*}$ & 0.001
\end{tabular}

PT: prothrombin time, INR:international normalized ratio, a PTT :activated prothrombin time, ACT: Activated clotting time. Values are expressed as mean(SD).

${ }^{\star} \mathrm{P}$-value $<0.05$ in comparison to preoperative level.

Table 5. Blood losses and blood products transfusion .

\begin{tabular}{lccc}
\hline Item & Group A(n=50) & Group B(n=50) & P-value \\
\hline Blood loss (ml/24hour) & $775.38 \pm 116.69$ & $1125.00 \pm 151.95$ & 0.001 \\
P-RBC (unit) & $2.95 \pm 0.71$ & $5.43 \pm 1.31$ & 0.001 \\
Platelets (unit) & $2.98 \pm 2.37$ & $6.65 \pm 4.08$ & 0.001 \\
FFP (unit) & $2.95 \pm 2.06$ & $7.33 \pm 4.01$ & 0.001 \\
Cryoprecipitate (unit) & $2.45 \pm 2.05$ & $5.75 \pm 3.84$ & 0.001 \\
HB(g/dl) & $11.14 \pm 1.18$ & $10.89 \pm 0.92$ & 0.513 \\
\hline
\end{tabular}

P-RBC: packed- red blood cells, FFP: fresh frozen plasma, HB: hemoglobin. Values are expressed as mean(SD).

\section{Blood losses and blood products transfusion}

The mean blood loss during the first 24 postoperative hours was $775.38 \pm 116.69 \mathrm{ml}$ in group $A$ and $1125.00 \pm 151.95 \mathrm{ml}$ in group $B(P=0.001)$. The number of transfused packed $R B C$ units, was $2.95 \pm 0.71$ unit in group $A$ and $5.43 \pm 1.31$ unit in group $B(P=0.001)$. Group $A$ patients received $2.98 \pm 2.37$ unit compared to $6.65 \pm 4.08$ unit in group $B$ patients $(P=0.001)$. Also the number of fresh frozen plasma units was $2.95 \pm 2.06$ in group $A$ compared to $7.33 \pm 4.01$ unit in group $B(P=0.001)$. Similarly, the number of cryoprecipitate units received in group A was $2.45 \pm 2.05$ compared to $5.75 \pm 3.84$ in group $\mathrm{B}(\mathrm{P}=0.001)$ (Table 5).

\section{Troponin I}

The mean preoperative troponin I level was $0.046 \pm 0.128$
Table 6. Postoperative outcomes.

\begin{tabular}{|c|c|c|c|c|}
\hline \multicolumn{2}{|l|}{ Item } & $\begin{array}{c}\text { Group A } \\
(\mathbf{n}=50)\end{array}$ & $\begin{array}{c}\text { Group B } \\
(n=50)\end{array}$ & P-value \\
\hline \multicolumn{2}{|c|}{ Creatinine $(\mathrm{mmol} / \mathrm{l})$} & $100 \pm 28^{*}$ & $93 \pm 24^{*}$ & 0.065 \\
\hline \multicolumn{2}{|c|}{ Renal impairment } & $6(12 \%)$ & $4(8 \%)$ & 0.460 \\
\hline \multicolumn{2}{|c|}{ Postoperative ARF and HD } & $4(8 \%)$ & $2(4 \%)$ & 0.325 \\
\hline \multicolumn{2}{|l|}{ AMI } & $2(4 \%)$ & $1(2 \%)$ & 1.000 \\
\hline \multicolumn{2}{|c|}{ Tropinin I(ng/ml) } & $1.02 \pm 0.56^{*}$ & $\begin{array}{l}0.90 \pm \\
0.66^{*}\end{array}$ & 0.362 \\
\hline \multicolumn{2}{|c|}{$\begin{array}{l}\text { Neurological } \\
\text { complication(stroke) }\end{array}$} & $1(2 \%)$ & $2(4 \%)$ & 1.000 \\
\hline \multicolumn{2}{|l|}{ DVT } & - & - & - \\
\hline \multicolumn{2}{|l|}{ DIC } & - & - & - \\
\hline \multirow[t]{2}{*}{ Mortality } & $\begin{array}{l}\text { Early(within one } \\
\text { week) }\end{array}$ & $1(2 \%)$ & $2(4 \%)$ & 1.000 \\
\hline & $\begin{array}{l}\text { Late (after one } \\
\text { week) }\end{array}$ & $1(2 \%)$ & $1(2 \%)$ & 1.000 \\
\hline \multicolumn{2}{|l|}{ MOF } & $1(2 \%)$ & $1(2 \%)$ & 1.000 \\
\hline \multicolumn{5}{|c|}{$\begin{array}{l}\text { ARF:acute renal failue, HD hemodialysis, AMI: acute myocardial } \\
\text { infarction, DVT:deep venous thrombosis, DIC:disseminated } \\
\text { intravascular coagulopathy, MOF: multisystem organ failure. Values } \\
\text { are expressed as mean(SD), numbers (\%). }\end{array}$} \\
\hline
\end{tabular}

$\mathrm{ng} / \mathrm{ml}$ in group $A$ and $0.041 \pm 0.149 \mathrm{ng} / \mathrm{ml}$ in group $B(P=0.736)$. Postoperatively, there was mild elevation of troponin I in patients of both groups, but there was no ECG changes or hemodynamic instability. The mean postoperative troponin I level in group A was $1.02 \pm 0.56 \mathrm{ng} / \mathrm{ml}$ and in group $B$ was $0.90 \pm 0.66 \mathrm{ng} / \mathrm{ml}(P=0.362)$. In both groups, the postoperative Troponin I level increased in comparison to the preoperative level $(P<0.05)$ (Tables 1,6).

\section{Creatinine level}

There was no significant difference between the mean preoperative creatinine level in groups $A$ and $B(74 \pm 22$ vs $79 \pm 25$ $\mathrm{mmol} / \mathrm{l}$, respectively, $\mathrm{P}=0.633$ ). The postoperative creatinine level increased in both groups, but still there was no significant difference between groups $A$ and $B(100 \pm 28 \mathrm{mmol} / \mathrm{l}$ vs $93 \pm 24 \mathrm{mmol} / \mathrm{l}, \mathrm{P}=0.065)$. Four patients in group $A$ suffered from acute renal failure and 2 patients in group $B(P=0.05)$. and renal dialysis was needed for all those patients (Table 1,6).

\section{Postoperative outcomes}

There were 2 patients with acute myocardial infarction (AMI) in group $A$ and one patient in group $B(P=1.000)$, one patient with stroke (diagnosed by brain CT-scan) in group $A$ and 2 patients in group $B(P=1.000)$. One case in group $A$ suffered from multisystem organ failure involving the lung (acute respiratory distress syndrome), the kidneys, the liver, and the heart (low cardiac output) as well as one case in group $B(P=1.000)$. One case in group $A$ and 2 cases in group $B$ died due to intractable cardiogenic shock (within one week), as well as one case in each group due to multisystem organ failure (after one week) ( $P>0.05$ ) (Table 6). No cases in either 
group suffered from seizures, disseminated intravascular coagulopathy (DIC) or deep venous thrombosis.

\section{Discussion}

Cardiovascular surgery is associated with a remarkable use of allogenic blood products. Minimizing blood losses and transfusion requirements is of vital importance in cardiac surgery to avoid complication related to blood products transfusion. These complications may include increased risk for transfusion related reactions or infections, hypothermia, DIC, excessive fibrinolysis, dilutional coagulopathy, and metabolic acidosis, which may further exacerbate bleeding. Renal failure, arrhythmias, prolonged requirement for mechanical ventilation, longer hospital stay and increased mortality may also occur $[15,16,17]$.

Our study showed that patients who received aprotinin during cardiac surgery had significantly lower blood losses and blood products transfusion compared to patients who received tranexamic acid $(P<0.05)$. Later et al., indicated that aprotinin was about twice as effective as tranexamic acid in reducing total postoperative blood losses $(P<0.001)$ and aprotinin reduced packed red blood cell transfusions more than tranexamic acid, although the difference did not reach statistical significance [18]. A prospective, randomized, double-blind study was done by Dietrich et al., enrolled 220 patients undergoing CABG or aortic valve replacement (AVR). The study demonstrated that, in the aprotinin group $47 \%$ of patients received allogenic blood during the hospital stay as compared to $61 \%$ in the tranexamic acid group $(P=0.036)$ [19]. Other studies had the same results $[20,21,22]$.

In our study, there were no significant differences regarding the coagulation profiles (PT, INR, aPTT, ACT, platelets) between the two groups $(P>0.05)$. The heparin dosage between the two groups during $C P B$ were also insignificant $(P>0.05)$. Despotis GJ et al., and Valter C. et al., reported that aPTT was significantly longer in the aprotinin group. This difference is due to the inhibition of the bean phosphatide activator used in the whole blood aPTT assay induced by aprotinin $[23,24]$. One study showed that heparin requirements were significantly reduced with aprotinin more than with tranexamic acid $(P<0.001)$ [19].

The difference in the incidence of AMI between the two groups was insignificant $(P>0.05)$. In spite of the elevated postoperative troponin I level in both groups in comparison to the preoperative level, there was no ECG changes and the elevated troponin may be due to myocardial injury after cardiotomy in cases associated with valvular surgery. Another study showed that troponin T levels postoperatively and on postoperative day 1 were significantly higher in the TA group $(P=0.017)$, but finally, no difference in cardiac outcomes was observed [19]. Others have demonstrated an increased risk of AMI with aprotinin [25] and that administration of aprotinin should be avoided in coronary artery bypass graft and high-risk patients [26].
In our study, there were significant elevated levels of postoperative D-dimer and decreased fibrinogen with TA more than with aprotinin and this means that aprotinin decreases the fibrinolysis during CPB more than tranexamic acid and also this may explain the decreased blood losses and the decreased need for blood products. However, Barbara et al., reported that the concentrations of D-dimer remained at baseline in the recipients of aprotinin and TA acid but tripled in the controls $(P<0.05)$ [27]. One study showed that, at all times intraoperatively and postoperatively, levels of $D$-dimer were greatly decreased with aprotinin and TA versus control $(\mathrm{P}<0.001)$, indicating that fibrinolysis persists after surgery [28]. Contrary to our findings, Valter et al., showed no difference in the levels of fibrinogen and D-dimer with time between tranexamic acid and aprotinin ( $P>0.05)$ [24].

There was no increase in mortality between the two study groups $(P>0.05)$, and early mortality in both groups was due to severe preoperative AMI and refractory cardiogenic shock. Postoperatively, the patients were on inotropic supports and intra-aortic balloon pump. Late mortality was due to multisystem organ failure [acute respiratory distress syndrome, kidney, liver, heart (low cardiac output)] and severe sepsis. One study demonstrated that aprotinin decreases mortality in cardiac surgery [29]. In contrast another study showed that neither antifibrinolytic agents increased the incidence of mortality ( $P=0.62$ compared with placebo) [18], while others have demonstrated an increased incidence of mortality with aprotinin [25].

In our study, there was a trend for a higher incidence of postoperative renal failure and hemodialysis in the aprotinin group compared to the TA group ( $8 \%$ vs $4 \%$ respectively). However, this did not reach statistical significance $(P=0.325)$, most probably due to the small sample size. Several previous retrospective studies have shown aprotinin to be associated with an increased risk of postoperative renal failure $[25,30,31,32]$. In contrast, a prospective, randomized, placebo-controlled trial showed no significant difference between aprotinin and control groups on kidney function postoperatively [33]. Also several retrospective studies have shown no increased incidence of dialysis in aprotinin-treated patients compared with control $[22,34,35,36]$. So, there is a certain degree of controversy over the effect of aprotinin on kidney function postoperatively.

In our study, cerebral stroke affected one case in group A and 2 cases in group $B(P>0.05)$. Those patients had bilateral carotid artery stenosis preoperatively, and it is possible that the cerebral insult was due to hypoperfusion or embolization from aortic cannulation during CPB. There was no postoperative seizures. However, other studies reported an increase in the number of seizures in patients treated with tranexamic acid $[34,37]$. This can be explained by the antagonistic effect of tranexamic acid on gamma-aminobutyric acid (GABA) receptors [38]. Some investigators have demonstrated that aprotinin decreases the incidences of stroke or encephalopa- 
thy $[36,39]$ and other have demonstrated an increased risk of stroke or encephalopathy [25].

\section{Conclusion}

Aprotinin decreases fibrinolysis, blood losses, and the need for blood products transfusion in comparison to TA during adult cardiac surgery. However, it was associated with a trend for an increased incidence of acute renal failure. Use of aprotinin should be useful for cases at high risk for bleeding such as redo surgery. It should be used cautiously in patients with preoperative renal impairment.

\section{Limitations}

Our study recognizes some limitations such as being single center study as well the small number of patients. Another shortcoming of this study, is the absence of a control group.

\section{Competing interests}

The authors declare that they have no competing interests.

Publication history

Received: 26-Oct-2012 Revised: 10-Dec-2012

Accepted: 02-Jan-2013 Published: 16-Feb-2013

\section{References}

1. Magovern JA, Sakert T, Benckart DH, Burkholder JA, Liebler GA, Magovern GJ, Sr. and Magovern GJ: A model for predicting transfusion after coronary artery bypass grafting. Ann Thorac Surg 1996, 61:27-32. | Article | PubMed

2. Moulton MJ, Creswell LL, Mackey ME, James L. Cox, Michael Rosenbloom . Re-exploration for bleeding is a risk factor for adverse outcomes after cardiac operations. J Thorac Cardiovasc Surg 1996, 111:1037-1046. | Article

3. Boyle EM, Jr., Verrier ED and Spiess BD: Endothelial cell injury in cardiovascular surgery: the procoagulant response. Ann Thorac Surg 1996, 62:1549-57. | Article | PubMed

4. Slaughter TF, Faghih F, Greenberg CS, Leslie JB and Sladen RN: The effects of epsilon-aminocaproic acid on fibrinolysis and thrombin generation during cardiac surgery. Anesth Analg 1997, 85:1221-6. | Article I PubMed

5. Bracey AW and Radovancevic R: The hematologic effects of cardiopulmonary bypass and the use of hemotherapy in coronary artery bypass grafting. Arch Pathol Lab Med 1994, 118:411-6. I Article | PubMed

6. Scott WJ, Kessler R and Wernly JA: Blood conservation in cardiac surgery. Ann Thorac Surg 1990, 50:843-51. | Article I PubMed

7. Kojima T, Gando S, Kemmotsu O, Mashio H, Goda Y, Kawahigashi H and Watanabe N: Another point of view on the mechanism of thrombin generation during cardiopulmonary bypass: role of tissue factor pathway inhibitor. J Cardiothorac Vasc Anesth 2001, 15:60-4. | Article | PubMed

8. Chabbat J, Porte P, Tellier M and Steinbuch M: Aprotinin is a competitive inhibitor of the factor VIla-tissue factor complex. Thromb Res 1993, 71:205-15. | Article | PubMed

9. Horrow J. Transfusion medicine and coagulation disorders. In: Kaplan JA, editor. Cardiac Anesthesia. Philadelphia:WB Saunders; 1987, 11111154.

10. Despotis GJ, Avidan MS and Hogue CW, Jr.: Mechanisms and attenuation of hemostatic activation during extracorporeal circulation. Ann Thorac Surg 2001, 72:S1821-31. | Article | PubMed

11. Marx G, Pokar $H$, Reuter $H$, Doering $V$ and Tilsner $V$ : The effects of aprotinin on hemostatic function during cardiac surgery. $J$
Cardiothorac Vasc Anesth 1991, 5:467-74. | Article | PubMed

12. Mannucci PM: Hemostatic drugs. N Engl J Med 1998, 339:245-53. | Article I PubMed

13. Dunn CJ and Goa KL: Tranexamic acid: a review of its use in surgery and other indications. Drugs 1999, 57:1005-32. | Article I PubMed

14. Bellomo R, Ronco C, Kellum JA, Mehta RL and Palevsky P: Acute renal failure - definition, outcome measures, animal models, fluid therapy and information technology needs: the Second International Consensus Conference of the Acute Dialysis Quality Initiative (ADQI) Group. Crit Care 2004, 8:R204-12. | Article | PubMed Abstract | PubMed Full Text

15. Porte RJ and Leebeek FW: Pharmacological strategies to decrease transfusion requirements in patients undergoing surgery. Drugs 2002, 62:2193-211. | Article | PubMed

16. Dahlback B: Blood coagulation. Lancet 2000, 355:1627-1633. | Article

17. Chelemer SB, Prato BS, Cox PM, Jr., O'Connor GT and Morton JR: Association of bacterial infection and red blood cell transfusion after coronary artery bypass surgery. Ann Thorac Surg 2002, 73:138-42. Article I PubMed

18. Later AF, Maas JJ, Engbers FH, Versteegh MI, Bruggemans EF, Dion RA and Klautz RJ: Tranexamic acid and aprotinin in low- and intermediate-risk cardiac surgery: a non-sponsored, double-blind, randomised, placebo-controlled trial. Eur J Cardiothorac Surg 2009, 36:322-9. | Article | PubMed

19. Dietrich W, SpannagI M, Boehm J, Hauner K, Braun S, Schuster T and Busley R: Tranexamic acid and aprotinin in primary cardiac operations: an analysis of $\mathbf{2 2 0}$ cardiac surgical patients treated with tranexamic acid or aprotinin. Anesth Analg 2008, 107:1469-78. | Article I PubMed

20. Fergusson DA, Hebert PC, Mazer CD, Fremes S, MacAdams $C$, Murkin JM, Teoh K, Duke PC, Arellano R, Blajchman MA, Bussieres JS, Cote D, Karski J, Martineau R, Robblee JA, Rodger M, Wells G, Clinch J and Pretorius R: A comparison of aprotinin and lysine analogues in high-risk cardiac surgery. N Engl J Med 2008, 358:2319-31. | Article | PubMed

21. Waldow T, Krutzsch D, Wils M, Plotze $K$ and Matschke K: Low dose aprotinin and low dose tranexamic acid in elective cardiac surgery with cardiopulmonary bypass. Clin Hemorheol Microcirc 2009, 42:26977. | Article | PubMed

22. Mengistu AM, Rohm KD, Boldt J, Mayer J, Suttner SW and Piper SN: The influence of aprotinin and tranexamic acid on platelet function and postoperative blood loss in cardiac surgery. Anesth Analg 2008, 107:391-7. | Article | PubMed

23. Despotis GJ, Alsoufiev A, Goodnough LT and D G Lappas: Aprotinin prolongs whole blood activated partial thromboplastin time but not whole blood prothrombin time in patients undergoing cardiac surgery. Anesth Analg 1995, 81:919-924. I Article

24. Casati V, Guzzon D, Oppizzi M, Bellotti F, Franco A, Gerli C, Cossolini M, Torri G, Calori G, Benussi S and Alfieri O: Tranexamic acid compared with high-dose aprotinin in primary elective heart operations: effects on perioperative bleeding and allogeneic transfusions. J Thorac Cardiovasc Surg 2000, 120:520-7. | Article | PubMed

25. Karkouti K, Beattie WS, Dattilo KM, McCluskey SA, Ghannam M, Hamdy A, Wijeysundera DN, Fedorko L and Yau TM: A propensity score case-control comparison of aprotinin and tranexamic acid in hightransfusion-risk cardiac surgery. Transfusion 2006, 46:327-38. | Article | PubMed

26. Martin K, Wiesner G, Breuer T, Lange R and Tassani P: The risks of aprotinin and tranexamic acid in cardiac surgery: a one-year followup of 1188 consecutive patients. Anesth Analg 2008, 107:1783-90. | Article I PubMed

27. Blauhut B, Harringer W, Bettelheim P, Doran JE, Spath P and Lundsgaard-Hansen P: Comparison of the effects of aprotinin and tranexamic acid on blood loss and related variables after cardiopulmonary bypass. J Thorac Cardiovasc Surg 1994, 108:1083-91. | Article | PubMed

28. Misfeld M, Dubbert S, Eleftheriadis S, Siemens HJ, Wagner T and 
Soliman et al. Journal of Anesthesiology and Clinical Science 2013, http://www.hoajonline.com/journals/pdf/2049-9752-2-13.pdf

Sievers HH: Fibrinolysis-adjusted perioperative low-dose aprotinin reduces blood loss in bypass operations. Ann Thorac Surg 1998, 66:792-9. | Article | PubMed

29. Levi $M$, Cromheecke $M E$, de Jonge $E$, Prins $M H$, de Mol BJ, Briet $E$ and Buller HR: Pharmacological strategies to decrease excessive blood loss in cardiac surgery: a meta-analysis of clinically relevant endpoints. Lancet 1999, 354:1940-7. | Article | PubMed

30. Mangano DT, Tudor IC and Dietzel C: The risk associated with aprotinin in cardiac surgery. N Engl J Med 2006, 354:353-65. | Article I PubMed

31. Augoustides JG, Pochettino A, Ochroch EA, Cowie D, Weiner J, Gambone AJ, Pinchasik D, Bavaria JE and Jobes DR: Renal dysfunction after thoracic aortic surgery requiring deep hypothermic circulatory arrest: definition, incidence, and clinical predictors. J Cardiothorac Vasc Anesth 2006, 20:673-7. I Article | PubMed

32. Schneeweiss S, Seeger JD, Landon J and Walker AM: Aprotinin during coronary-artery bypass grafting and risk of death. N Engl J Med 2008, 358:771-83. | Article | PubMed

33. Lemmer JH, Jr., Stanford W, Bonney SL, Chomka EV, Karp RB, Laub GW, Rumberger JA and Schaff HV: Aprotinin for coronary artery bypass grafting: effect on postoperative renal function. Ann Thorac Surg 1995, 59:132-6. | Article | PubMed

34. Levy JH, Pifarre R, Schaff HV, Horrow JC, Albus R, Spiess B, Rosengart TK, Murray J, Clark RE and Smith P: A multicenter, double-blind, placebo-controlled trial of aprotinin for reducing blood loss and the requirement for donor-blood transfusion in patients undergoing repeat coronary artery bypass grafting. Circulation 1995, 92:2236-44. | Article I PubMed

35. Harmon DC, Ghori KG, Eustace NP, O'Callaghan SJ, O'Donnell AP and Shorten GD: Aprotinin decreases the incidence of cognitive deficit following CABG and cardiopulmonary bypass: a pilot randomized controlled study. Can J Anaesth 2004, 51:1002-9. | Article | PubMed

36. Furnary AP, Wu Y, Hiratzka LF, Grunkemeier GL and Page US, 3rd: Aprotinin does not increase the risk of renal failure in cardiac surgery patients. Circulation 2007, 116:1127-33. | Article | PubMed

37. Breuer T, Martin K, Wilhelm M, Wiesner G, Schreiber C, Hess J, Lange $R$ and Tassani $P$ : The blood sparing effect and the safety of aprotinin compared to tranexamic acid in paediatric cardiac surgery. Eur $J$ Cardiothorac Surg 2009, 35:167-71; author reply 171. | Article | PubMed

38. Furtmuller R, Schlag MG, Berger M, Hopf R, Huck S, Sieghart W and Redl $\mathrm{H}$ : Tranexamic acid, a widely used antifibrinolytic agent, causes convulsions by a gamma-aminobutyric acid(A) receptor antagonistic effect. J Pharmacol Exp Ther 2002, 301:168-73. | Article | PubMed

39. Murkin JM: Attenuation of neurologic injury during cardiac surgery. Ann Thorac Surg 2001, 72:S1838-44. | Article | PubMed

\section{Citation:}

soliman $\mathrm{R}$, yousef $\mathrm{H}$, alghadam $\mathrm{F}$, ragheb $\mathrm{A}$, hussien $\mathrm{M}$, al qethamy $\mathrm{H}$, belghith $\mathrm{M}$ and abdel mageed $\mathrm{T}$ : Prospective, Randomized, comparative study between aprotinin and tranexamic acid in cardiac surgery. journal of Anesthesiology and Clinical Science 2013, 2:13. http://dx.doi.org/10.7243/2049-9752-2-13 